\title{
A Conceptual Model for the Creation of a Process- Oriented Knowledge Map (POK-Map) and Implementation in an Electric Power Distribution Company
}

\author{
Babak Teimourpour and Vahid Eslami \\ Department of Industrial Engineering, \\ Tarbiat Modares University, Tehran, Iran
}

B.Teimourpour@modares.ac.ir; V.Eslami@modares.ac.ir

Maghsoud Mohammadi

Department of Training and HR Planning, East Azarbaijan Electric Power Distribution Company, Tabriz, Iran

Mohamadi@Ezepdico.ir

\section{Milad Padidarfard Department of Industrial Management, Islamic Azad University Firoozkooh Branch, Tehran, Iran}

Milad Padidar@yahoo.com

\begin{abstract}
Helping a company organize and capture the knowledge used by its employees and business processes is a daunting task. In this work we examine several proposed methodologies and synthesize them into a new methodology that we demonstrate through a case study of an electric power distribution company. This is a practical research study. First, the research approach for creating the knowledge map is process-oriented and the processes are considered as the main elements of the model. This research was done in four stages: literature review, model editing, model validation and case study. The Delphi method was used for the research model validation. Some of the important outputs of this research were mapping knowledge flows, determining the level of

Material published as part of this publication, either on-line or in print, is copyrighted by the Informing Science Institute. Permission to make digital or paper copy of part or all of these works for personal or classroom use is granted without fee provided that the copies are not made or distributed for profit or commercial advantage AND that copies 1) bear this notice in full and 2) give the full citation on the first page. It is permissible to abstract these works so long as credit is given. To copy in all other cases or to republish or to post on a server or to redistribute to lists requires specific permission and payment of a fee. Contact Publisher@InformingScience.org to request redistribution permission.

knowledge assets, expert-area knowledge map, preparing knowledge meta-model, and updating the knowledge map according to the company's processes. Besides identifying, auditing and visualizing tacit and explicit knowledge, this knowledge mapping enables us to analyze the knowledge areas' situation and subsequently help us to improve the processes and overall performance. So, a process map does
\end{abstract}


knowledge mapping in a clear and accurate frame. Once the knowledge is used in processes, it creates value.

Keywords: Knowledge mapping, knowledge breakdown structure, knowledge levelling, business-process oriented knowledge management, knowledge meta-model

\section{Introduction}

In order to effectively manage knowledge in organizations, knowledge workers and managers need to know the organizational knowledge resources and flows well. A knowledge map is a useful technique to reach this goal. Knowledge maps provide clear, purposeful and structured images of the existing knowledge in the organization. There are different approaches for preparing knowledge maps but only some are based on organizational processes. A knowledge map lets the users know "who knows what?" and "where is the location of knowledge in the organization?" (Holsapple, 2004). It also shows the existing knowledge and its flow in the specialized areas of the organization. Knowledge models are prepared in the frame of goals and knowledge processes of the organization, and organizational memory is created with the help of knowledge maps, which in turn prevents rework, and a waste of time and money (Wexler, 2001).

Some of the challenges that companies are facing due to the lack of knowledge maps are:

- They have problems in doing some of the organizational duties and missions and they do not know who has the knowledge and ability to help.

- The process of solving problems that has happened before happens again and again because the learning from them is not documented (Tserng, Yin, \& Lee, 2010).

- They do not have a proper criterion for evaluating knowledge in the work processes.

- They do not know the available knowledge areas on the way of implementing organizational projects or processes, and what the situation is in each of them.

Knowledge maps have significantly contributed to the success of knowledge management in the company in a way that identifying, measuring and visualizing the knowledge resources of the company is considered as part of the main process of knowledge management (Subrt \& Brozova, 2007; Farquharson, 2004).

Knowledge mapping is a tool for determining the knowledge layout in the organization and helps the knowledge presentation using different knowledge maps. Identification and modeling of the knowledge areas that directly and indirectly help the organization to reach its strategic objectives are the basic steps in any knowledge management planning (Busch, Richards, \& Dampney, 2001). Knowledge mapping reveals the knowledge assets of the organization to the entire workforce who have access to them. These maps connect the experts to each other and allow the novices to identify the experts faster and use their experience and skills to solve their problems (Kim, Suh, \& Hwang, 2003). They further assist in a faster search process and access to the necessary knowledge by the workers, and reduce the working time. Some advantages of knowledge mapping are:

- $\quad$ analyzing knowledge and arranging elements together;

- introducing the company's knowledge and experiences, as well as workers' knowledge and their place in the company (Chen, Lin, \& Tsui, 2007);

- detecting the role and place of each knowledge relative to other fields;

- identifying the current knowledge situation and necessary knowledge and determining the existing gaps in the knowledge areas;

- determining the effect of knowledge areas on key performance indicators (KPIs), which are measures that emphasize and focus on aspects that play a significant role in an organization's current and future success (Dabbagh, 2001); 
- avoiding the purchase of repeated knowledge;

- lessons learned management (LLM) in projects and learning from previous experiences; and

- $\quad$ avoiding workers' knowledge and experiences exiting after they leave the company (for reasons such as retirement, resignation and management changes) (Buesser \& Ninck, 2004; Wexler, 2001).

\section{Literature Review}

Drawing a knowledge map is a process with which organizations can identify knowledge assets within the organization (individuals, processes, contents and technology). A knowledge map tries to answer some basic questions about the organization:

- Who has which kind of knowledge (implicit and explicit knowledge)?

- Where are the persons who have knowledge?

- Where is the location of knowledge in the organization?

The map of knowledge shows which knowledge is used in a process and how it goes through that process. Organizational processes are defined in terms of main, managing and supporting processes. Basically, the central core of the activities of an organization is formed by its main processes containing the key knowledge of the organization.

The place of knowledge in parts of the process can be explained as follows:

A. Knowledge, one of the processes' inputs

To increase the efficiency of the business processes in the organization, knowledge as one of the inputs of business processes as required knowledge (basic) must be used and considered by those who are liable for that process.

B. Knowledge in performing activities

Using the knowledge in this step of the process mostly depends on the creativity, experience and proficiency of the employees.

C. Knowledge in processes' output

In this step of the process, the organization produces the intended outputs using inputs and specified activities. What leads to differences in outputs of the process as time passes is utilization of results and experiences of doing the process in the past. These results are considered in organizations as different titles like recording the experiences, documentation of proceedings and knowledge.

\section{Knowledge control}

Control, as one of the main activities of business processes in the organization, checks and evaluates the resultant outputs of the process in order to improve the progress of the process in the future. Due to the fact that the produced knowledge was mentioned as one of the processes' inputs, the produced knowledge must be checked and evaluated by experts and some procedures and eventually the confirmed knowledge must be used again as one of the processes' inputs in order to make improvements in the future.

The place and steps of using the knowledge in business processes is shown in Figure 1.

We will now introduce different methods of organizational knowledge mapping. Although these stages might vary based on the chosen approach, there are similarities between them. Table 1 summarizes some methods of drawing and implementing knowledge maps. 


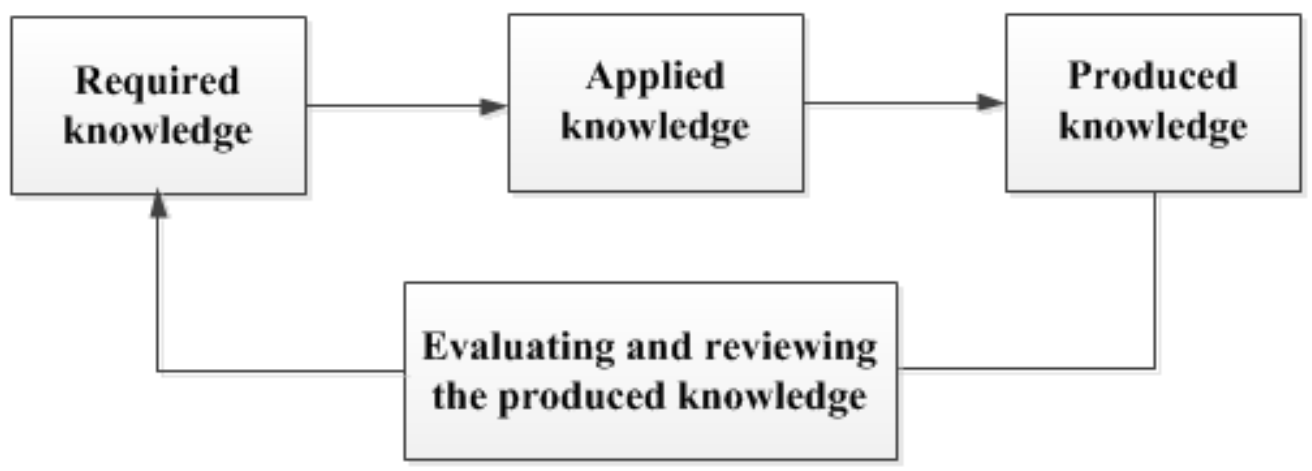

Figure 1. Place and steps of using the knowledge in a business process

Table 1. Some methods of drawing and implementing knowledge maps

\begin{tabular}{|c|c|c|c|c|c|}
\hline Method & Vail (1999) & Kim et al. (2003) & $\begin{array}{c}\text { APQC (2012); Vestal } \\
\text { \& Lopez (2003); } \\
\text { Vestal (2005) }\end{array}$ & $\begin{array}{c}\text { Lecocq } \\
(\mathbf{2 0 0 6 )}\end{array}$ & $\begin{array}{l}\text { Tserng et al. } \\
\text { (2010) }\end{array}$ \\
\hline $\begin{array}{c}\text { Steps } \\
\text { defined }\end{array}$ & $\begin{array}{l}\text { 12-step } \\
\text { methodology }\end{array}$ & $\begin{array}{c}\text { 6-step } \\
\text { methodology }\end{array}$ & $\begin{array}{c}\text { 8-step } \\
\text { methodology }\end{array}$ & $\begin{array}{c}\text { 11-step } \\
\text { methodolog } \\
y\end{array}$ & $\begin{array}{l}\text { 5-step meth- } \\
\text { odology }\end{array}$ \\
\hline 1 & $\begin{array}{l}\text { Identify the sponsor and } \\
\text { his or her objectives }\end{array}$ & $\begin{array}{l}\text { Defining organisa- } \\
\text { tional knowledge: } \\
\text { define ontology; de- } \\
\text { fine scope and level } \\
\text { of detail }\end{array}$ & $\begin{array}{l}\text { Select the process/fo- } \\
\text { cus area: review criti- } \\
\text { cal processes }\end{array}$ & $\begin{array}{l}\text { Identifying } \\
\text { objectives, } \\
\text { scope and } \\
\text { stakeholders }\end{array}$ & $\begin{array}{l}\text { Identifying } \\
\text { Problems }\end{array}$ \\
\hline 2 & $\begin{array}{l}\text { Determine what the } \\
\text { knowledge map is in- } \\
\text { tended for, the scope of } \\
\text { the map, and the specif- } \\
\text { ic knowledge map user } \\
\text { requirements }\end{array}$ & $\begin{array}{l}\text { Process map analy- } \\
\text { sis:extract organisa- } \\
\text { tional knowledge } \\
\text { based on the business } \\
\text { process, experience } \\
\text { and know-how ac- } \\
\text { quired during busi- } \\
\text { ness execution }\end{array}$ & $\begin{array}{l}\text { Identify the key busi- } \\
\text { ness value of mapping } \\
\text { the knowledge-who } \\
\text { will use it? }\end{array}$ & $\begin{array}{c}\text { Selecting } \\
\text { the mapping } \\
\text { engineering } \\
\text { team }\end{array}$ & $\begin{array}{l}\text { Discussing } \\
\text { with Experts } \\
\text { and Users }\end{array}$ \\
\hline 3 & $\begin{array}{l}\text { Begin an ongoing edu- } \\
\text { cation process on map- } \\
\text { ping's benefits and } \\
\text { requirements, starting } \\
\text { with the sponsor }\end{array}$ & $\begin{array}{l}\text { Knowledge extrac- } \\
\text { tion :through a pro- } \\
\text { cess map identify } \\
\text { prerequisite, used and } \\
\text { produced knowledge }\end{array}$ & $\begin{array}{c}\text { Map the processes: } \\
\text { determine rou- } \\
\text { tine/non-routine tasks; } \\
\text { identify key decision } \\
\text { points; locate owners } \\
\text { of, and stakeholders } \\
\text { in high-value process- } \\
\text { es }\end{array}$ & $\begin{array}{l}\text { Determining } \\
\text { right } \\
\text { balance } \\
\text { between } \\
\text { approaches }\end{array}$ & $\begin{array}{c}\text { Establishing } \\
\text { Classification } \\
\text { Structure }\end{array}$ \\
\hline 4 & $\begin{array}{l}\text { Identify the key stake- } \\
\text { holders (key users or } \\
\text { people who will be } \\
\text { impacted by the crea- } \\
\text { tion of the knowledge } \\
\text { map) }\end{array}$ & $\begin{array}{l}\text { Knowledge profiling: } \\
\text { give attributes to the } \\
\text { extracted knowledge; } \\
\text { derive relationships } \\
\text { with process }\end{array}$ & $\begin{array}{l}\text { Develop plan for col- } \\
\text { lecting, reviewing, } \\
\text { validating, storing and } \\
\text { sharing knowledge } \\
\text { and information }\end{array}$ & $\begin{array}{l}\text { Identifying } \\
\text { components }\end{array}$ & $\begin{array}{c}\text { Establishing } \\
\text { Document } \\
\text { Base }\end{array}$ \\
\hline 5 & $\begin{array}{l}\text { Create a knowledge } \\
\text { map steering committee } \\
\text { with direct representa- } \\
\text { tives of the key spon- } \\
\text { sors and stakeholders }\end{array}$ & $\begin{array}{l}\text { Knowledge linking: } \\
\text { examine profile made } \\
\text { in preceding step, } \\
\text { confirm or invalidate } \\
\text { existing links and } \\
\text { identify new ones }\end{array}$ & $\begin{array}{c}\text { Identify the } \\
\text { knowledge required: } \\
\text { categorise the } \\
\text { knowledge content } \\
\text { the social capital an } \\
\text { infrastructure }\end{array}$ & $\begin{array}{l}\text { Compiling } \\
\text { ontology }\end{array}$ & $\begin{array}{c}\text { Deciding the } \\
\text { Display } \\
\text { Model }\end{array}$ \\
\hline
\end{tabular}




\begin{tabular}{|c|c|c|c|c|c|}
\hline Method & Vail (1999) & Kim et al. (2003) & $\begin{array}{l}\text { APQC (2012); Vestal } \\
\text { \& Lopez (2003); } \\
\text { Vestal (2005) }\end{array}$ & $\begin{array}{c}\text { Lecocq } \\
(2006)\end{array}$ & $\begin{array}{c}\text { Tserng et al. } \\
(2010)\end{array}$ \\
\hline $\begin{array}{c}\text { Steps } \\
\text { defined }\end{array}$ & $\begin{array}{c}\text { 12-step } \\
\text { methodology }\end{array}$ & $\begin{array}{c}\text { 6-step } \\
\text { methodology }\end{array}$ & $\begin{array}{c}\text { 8-step } \\
\text { methodology }\end{array}$ & $\begin{array}{c}\text { 11-step } \\
\text { methodolog } \\
y \\
\end{array}$ & $\begin{array}{l}\text { 5-step meth- } \\
\text { odology }\end{array}$ \\
\hline 6 & $\begin{array}{l}\text { Create a corresponding } \\
\text { knowledge map tech- } \\
\text { nical committee }\end{array}$ & $\begin{array}{l}\text { Knowledge map Val- } \\
\text { idation: walkthrough } \\
\text { with users. subject } \\
\text { matter experts, busi- } \\
\text { ness managers and } \\
\text { knowledge map pro- } \\
\text { ducers } \\
\end{array}$ & $\begin{array}{l}\text { Analyse the map } \\
\text { (knowledge quality, } \\
\text { knowledge sharing, } \\
\text { ease of access, etc.). }\end{array}$ & $\begin{array}{l}\text { Conducting } \\
\text { inventory }\end{array}$ & \\
\hline 7 & $\begin{array}{c}\text { Develop a tool evalua- } \\
\text { tion and selection pro- } \\
\text { cess. }\end{array}$ & & $\begin{array}{l}\text { Identify gaps, lack of } \\
\text { connectivity, and } \\
\text { information overload }\end{array}$ & $\begin{array}{l}\text { Defining } \\
\text { and } \\
\text { selecting the } \\
\text { tools } \\
\end{array}$ & \\
\hline 8 & $\begin{array}{l}\text { Identify the custodian of } \\
\text { the map, the repository } \\
\text { location and the } \\
\text { maintenance process }\end{array}$ & & $\begin{array}{l}\text { Create measurement } \\
\text { criteria for each criti- } \\
\text { cal process step }\end{array}$ & $\begin{array}{l}\text { Crafting the } \\
\text { knowledge } \\
\text { map }\end{array}$ & \\
\hline 9 & $\begin{array}{l}\text { Create the initial enter- } \\
\text { prise knowledge map } \\
\text { and build the mapping } \\
\text { team }\end{array}$ & & & $\begin{array}{l}\text { Validating } \\
\text { the } \\
\text { knowledge } \\
\text { map }\end{array}$ & \\
\hline 10 & $\begin{array}{l}\text { Begin the mapping with } \\
\text { a bounded area of clear } \\
\text { business and IT interest } \\
\text { and importance. Look } \\
\text { for potential for an early } \\
\text { "quick-win" }\end{array}$ & & & $\begin{array}{l}\text { Exploiting } \\
\text { the } \\
\text { knowledge } \\
\text { map }\end{array}$ & \\
\hline 11 & $\begin{array}{l}\text { Work with acknowl- } \\
\text { edged experts and put } \\
\text { their names on The } \\
\text { map. Helps credibility } \\
\text { and confidence in the } \\
\text { map }\end{array}$ & & & $\begin{array}{l}\text { Revising, } \\
\text { maintaining } \\
\text { and } \\
\text { enhancing } \\
\text { the } \\
\text { knowledge } \\
\text { map } \\
\end{array}$ & \\
\hline 12 & $\begin{array}{c}\text { Disseminate the } \\
\text { knowledge maps } \\
\text { throughout the enter- } \\
\text { prise-as soon as the } \\
\text { initial maps are com- } \\
\text { pleted }\end{array}$ & & & & \\
\hline
\end{tabular}

Almost none of the current methods can fully meet the organizational knowledge needs. The current method of drawing and implementing knowledge maps shows four major weaknesses:

- lack of detailed description of the phases and details of knowledge mapping;

- not being based on an operational model;

- inefficiency in covering the knowledge exchange as well as internal and external knowledge flows; and

- lack of sufficient attention to the knowledge visualization stage.

Considering the above points, a comprehensive model is urgently needed for knowledge map generation in the company. First, by combining the strengths of the previous methods of knowledge mapping it should be able to: 
- classify the experts' knowledge;

- consider the knowledge indicators in drawing the knowledge map; and

- apply the company's future strategic focus to the knowledge map.

Second, the proposed model for this research should be able to:

- identify the knowledge capabilities and potential of experts and working groups (knowledge sources);

- identify the weak points and potential links between different knowledge areas (knowledge flows);

- provide an intuitive picture from the position of each knowledge area among the entire company's knowledge, along with the knowledge importance of each knowledge compared to other knowledge (Lecocq, 2006);

- create a systematic context to facilitate the knowledge planning;

- provide the necessary infrastructure for storing the knowledge and experiences in a systematic retrievable, editable and developable way;

- identify the building blocks of knowledge and evaluating based on them; and

- according to the organizational knowledge model, include the entire existing knowledge concepts and relations in the company (Milton, 2007).

Eventually, effective factors influencing the knowledge mapping are identified in a way that the final model, besides having the strengths of previously developed methods, should cover the hidden points and conform to the specific knowledge requirements of the mentioned company.

\section{Research Methodology}

This research is a practical study that proposes a revised model after examining relevant literature, and then shows how it can be implemented in an organization. The research was conducted in four main phases.

The First Phase includes a knowledge map literature review and identification of the weak points and strengths of the most important presented methods.

The Second Phase is generating the proposed model through combining previous methods and using other effective knowledge management approaches that have not been used before but can be very effective in a knowledge map.

The Third Phase is to validate the proposed model after consulting with professors and experts in academia and by seeking help from the experts in knowledge management during the survey stages (after obtaining their consent). The best way to validate this study is the Delphi method and the model was reviewed and improved in three stages.

In the last phase, i.e. the Fourth Phase, the proposed model was executed in a power distribution company and the goals of the company and the research were met.

\section{Model of Creating a Process-Oriented Knowledge Map}

Since continuous improvement is important in performing any process, identifying and recording the latent knowledge in inputs, and recording and codifying the applied knowledge for performing its activities, can be useful for improving the process and counting knowledge as a process output. In the suggested model, having a map actually expresses the knowledge flow in the organization and identifies its origin and its final application. When performing this model the organization is able to create and maintain its organizational memory. 
The reasons for preparing the knowledge map based on processes are:

- Documents, backgrounds and human resources are counted as inputs/outputs of the process.

- Processes rarely change within the organization, but the employees performing the processes can leave or change after some time for any reason.

- For the tools that control the parts of the process, including inputs, activities and outputs, the knowledge can be controlled as well as in all parts of it.

- Those responsible and their performance in using and producing knowledge in each process are specified.

- Knowledge indicators can be used as an efficient criterion in evaluating the performance.

Here, we describe the proposed model for creating a process-oriented knowledge map. The proposed model is a combination of the most important characteristics, which were mentioned in the previous knowledge mapping methods, along with other effective management solutions to increase efficiency and ease of the implementation of knowledge mapping projects. It should be noted that the implementation method varies according to the organization's requirements, depending on organizational limitations and needs. The suggested model is shown in Figure 2.

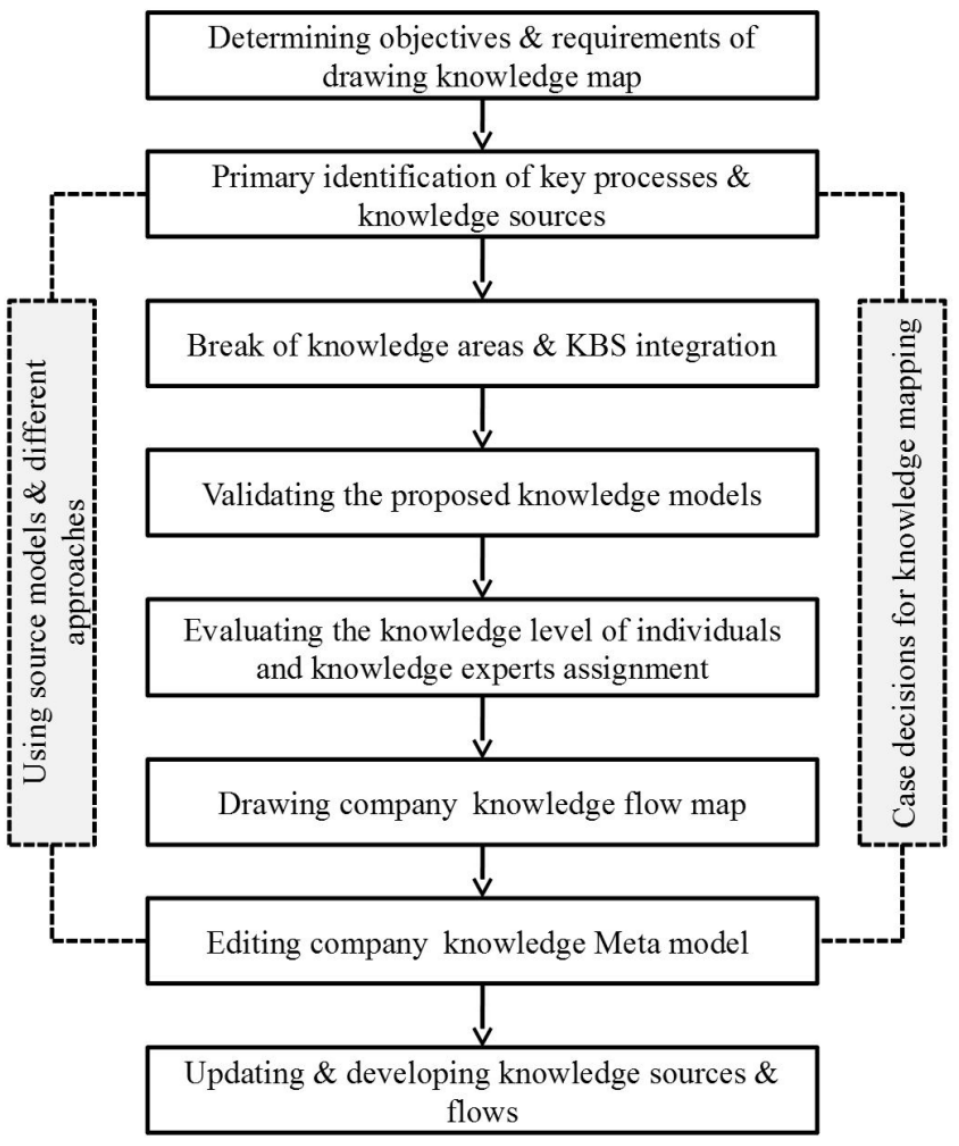

Figure 2. Model of creating process-oriented knowledge map 
Each of the steps is now discussed.

First step: Determining the objectives and prerequisites of drawing and implementing a knowledge map

Based on this model, first the organizational charter of the company is studied and the general objectives of drawing and implementing a knowledge map are defined. Also, among employees, those who are active in different departments and processes and are familiar with management concepts are chosen to cooperate in the stages of creating a knowledge map.

\section{Second step: Initial identification of key processes and knowledge sources}

Identification of key processes and knowledge resources are important in looking at the company's activities and identifying the main effective factors in achieving success. In this step the general scheme of main knowledge processes is identified.

\section{Third step: Breakdown of process-oriented knowledge areas and knowledge breakdown structure (KBS) integration}

This step shows the knowledge resources used for supporting business processes. The existing or necessary experience and expertise should be identified for managing a process. Following the main knowledge processes, knowledge areas are drawn based on the reference models, and after integration, the tree-structured knowledge areas. The experts' opinions are also collected.

\section{Fourth step: Validating the proposed knowledge models}

This phase includes validation of the knowledge models drawn by one or more experts, taking into account their opinions and adding explanations which lead to the generation of the final knowledge models.

\section{Fifth step: Evaluating the knowledge level of individuals and identifying knowledge experts}

The most important reason for knowledge classification is finding the weak points and problems of the company in terms of possessing the necessary knowledge to achieve organizational objectives. Knowledge classification is graded to classify knowledge from low to high. Different knowledge leveling approaches are used to evaluate one's knowledge level and identify the experts in every knowledge area. Choosing the proper approach depends on the type of knowledge to be classified and also the company's purpose for this classification.

\section{Sixth step: Drawing company knowledge flow map}

This step shows the knowledge exchanges and flows inside a specific department (department flows), knowledge flows between different departments of the organization (intra-department flows) and flows between departments and external partners (external flows). In order to share knowledge these flows in knowledge-based companies are formed independently from the formal structure and work flows.

\section{Seventh step: Developing company knowledge meta-model}

This phase includes making a meta-model for the company's knowledge base. A knowledge meta-model is a model that includes the entire knowledge models, and describes other models and the relations between them.

\section{Eighth step: Updating and developing knowledge sources and flows}

If knowledge areas and their relations change or expire, the knowledge map will be useless. So, a knowledge map needs to be updated constantly by its creators.

\section{Case decisions for knowledge mapping}


This step, which is embedded all the way from the first to the last step, can be done by the knowledge management steering committee and or different units' managers. It includes decision-making about:

- evaluating the situation of knowledge of the company and continuous audit of the knowledge according to the drawn knowledge map;

- checking if the drawn knowledge maps are based on the main processes and have clear perspectives; and

- checking if the knowledge models exploit individuals as process trustees, knowledge creators and engineers for creating, codification and dissemination of the presented knowledge in knowledge models

\section{Using process referral models}

Methods like classifying organizational processes according to the standard models, describing organizational processes through identifying serial input to output and vice versa, can be used to draw the knowledge map.

\section{Model Validation using the Delphi Method}

The Delphi method is carried out with the help of people who have expertise in the subject of the research. The group members are identified and the validity of the results mostly depends on their competency. The appropriate number of members is very important; nine to 20 members are recommended (Okoli \& Pawlowski, 2004). The Delphi groups for this research were chosen nonrandomly and sequentially using targeted or judgmental methods.

The next step was to ensure the candidates collaborated in the research. It should be done separately and face to face as much possible. So, separate appointments were arranged to review the purpose and subject of the research with each of the experts. They were also asked to introduce other experts. Finally due to the specialized nature of the subject and the timeframe for this research, ten experts fully participated in the entire process of the validation.

The final group selected had the expertise of:

1. University professors

2. Counselors of implementing knowledge management

3. Researchers of knowledge management

4. Chief knowledge managers

First phase: gathered comments and opinions of ten experts about the components, totality and effectiveness of the proposed model using a written questionnaire and then making a list of positive and negative opinions.

Second phase: a list was provided from the results of the first phase and sent to the experts for their opinion. Then they were asked to review their previous answers considering the answers of the rest of the experts and give their suggestions to improve the proposed model of this research. This led to a deeper consideration of the proposed model and its parts.

Third phase: the results of the second phase were sent to the respondents again. In this way optimal consensus was hopefully achieved after the third round and the validation of the proposed model was completed.

\section{Case Study}

Here we describe how we created and implemented a process-oriented knowledge map in an electric power distribution company, according to the proposed model. 


\section{First step: Necessities, objectives and prerequisites of drawing and implementing a knowledge map}

The studied company is one of the largest companies in power distribution and has the experience of executing many activities and projects in the whole province. Executing this large number of activities has led to experiences and lessons learned in the business processes during the time. It reflects that identifying, modeling and systematic developing the knowledge can have an effective role in enhancing the service processes in the power distribution field. This made the knowledge map implementation, for explicating and visualizing knowledge areas related to the power distribution, the agenda of the senior manager. In this step the necessary prerequisites for drawing and implementing the process-oriented knowledge map, considering the existing characteristics of the company, were identified and implemented. Some of these prerequisites were:

- training and informing about the role and necessity of a knowledge map in the power distribution network;

- forming a team for knowledge map generation consisting of chief knowledge officer, process trustees and the experienced experts of each unit;

- consensus about knowledge concepts; and

- exact review of the company charter including organizational structure, a list of company processes, value chain process, and so forth.

The most important goals of the power distribution company for drawing and implementing the knowledge map are:

- $\quad$ explication and representation of the company's knowledge;

- knowing who can solve the problems;

- a tool for the growth and reinforcement of the organizational memory;

- using a knowledge map for planning to resolve knowledge gaps; and

- a context for exchanging experiences and motivating people for innovation.

\section{Second step: Initial identification of processes and key knowledge sources}

The reason for using a process approach is that the knowledge of this company itself is not of value; it becomes so once the knowledge is used in the processes in order to achieve organizational goals and meet the needs of the company's stakeholders. After choosing the processoriented approach in the mentioned company, the standard classification models were studied. The APQC standard, which is applicable to the knowledge areas, was used as the main guide to edit the processes (APQC, 2012). So, after studying the general documentation, interviewing a number of key people and having a closer examination of the company's process map, the most important key knowledge processes in this step were identified and listed below:

- network development

- design and supervision

- Financial and support

- utilization

- $\quad$ sales and customer service

- human resource management

- management

Third step: Breakdown of process-oriented knowledge areas and Knowledge Breakdown Structure integration (KBS)

In the third step, relying on the key knowledge processes in the previous step, a field identification questionnaire and the company's knowledge areas were completed during interviews with the processes' trustees. The breakdown of knowledge areas was done by relying on the key 
knowledge processes and sub-processes, and collecting experts' opinions. Integrating the knowledge led to drawing knowledge models in each of the knowledge processes. Figure 3 shows the samples of knowledge areas (level 3) network development process (mother level) after the sub-processes (level 2):

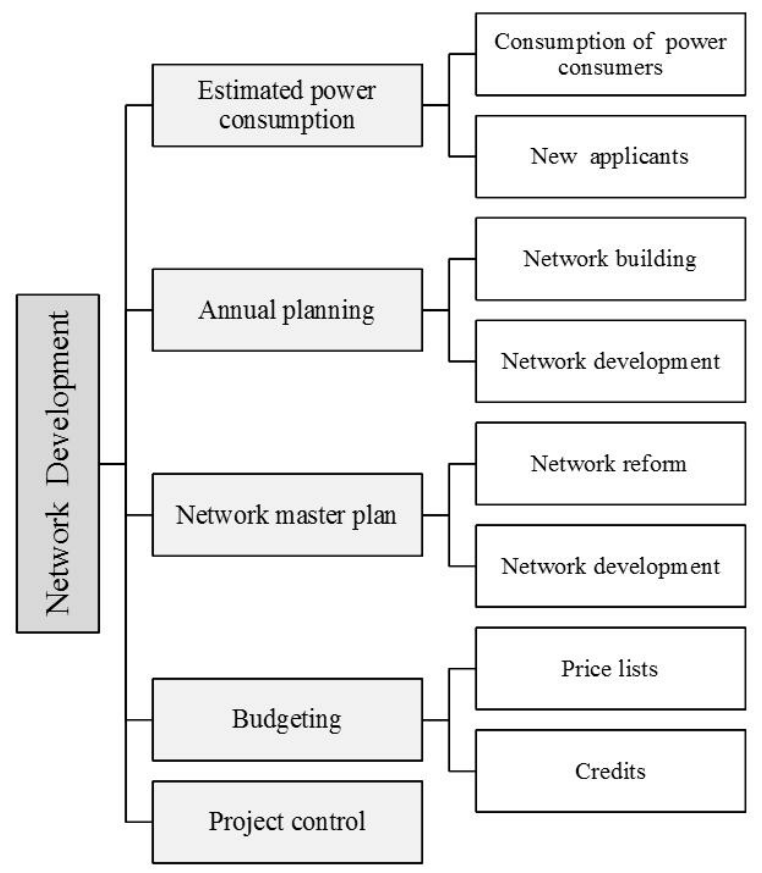

Figure 3. Network development process knowledge tree

The knowledge tree has two parts: rectangles to specify recorded knowledge from business processes; and relating lines to express sequences and relations between knowledge.

Next, each process manager was asked to score each knowledge area considering four indicators (amount of value adding from knowledge, knowledge importance, rate of being exclusive and risk of losing knowledge, and increase in stakeholder's satisfaction). Eventually, areas that gained a score of 15 or more were considered strategic knowledge areas. Table 2 shows the utilization process of knowledge areas along with the indicators and the scoring method for identifying strategic knowledge.

\section{Fourth step: Validating the drawn knowledge models}

After generating the knowledge models based on the main knowledge processes, knowledge models of each of the areas were sent to the senior experts of the company in the form of "correction questionnaires" to validate the models and evaluate their efficiency. They were asked to give their final opinion of knowledge categories and the knowledge relationships between them. Answers were required to questions such as:

- Have the entire knowledge areas of the company been identified?

- Which areas are unnecessary?

- Has use of knowledge models made improvements in the access and transfer of knowledge in the company?

Ultimately, the accuracy and validity of the knowledge models were confirmed. 
Table 2. Utilization process of knowledge areas along with the identification indicators of strategic knowledge and the scoring method

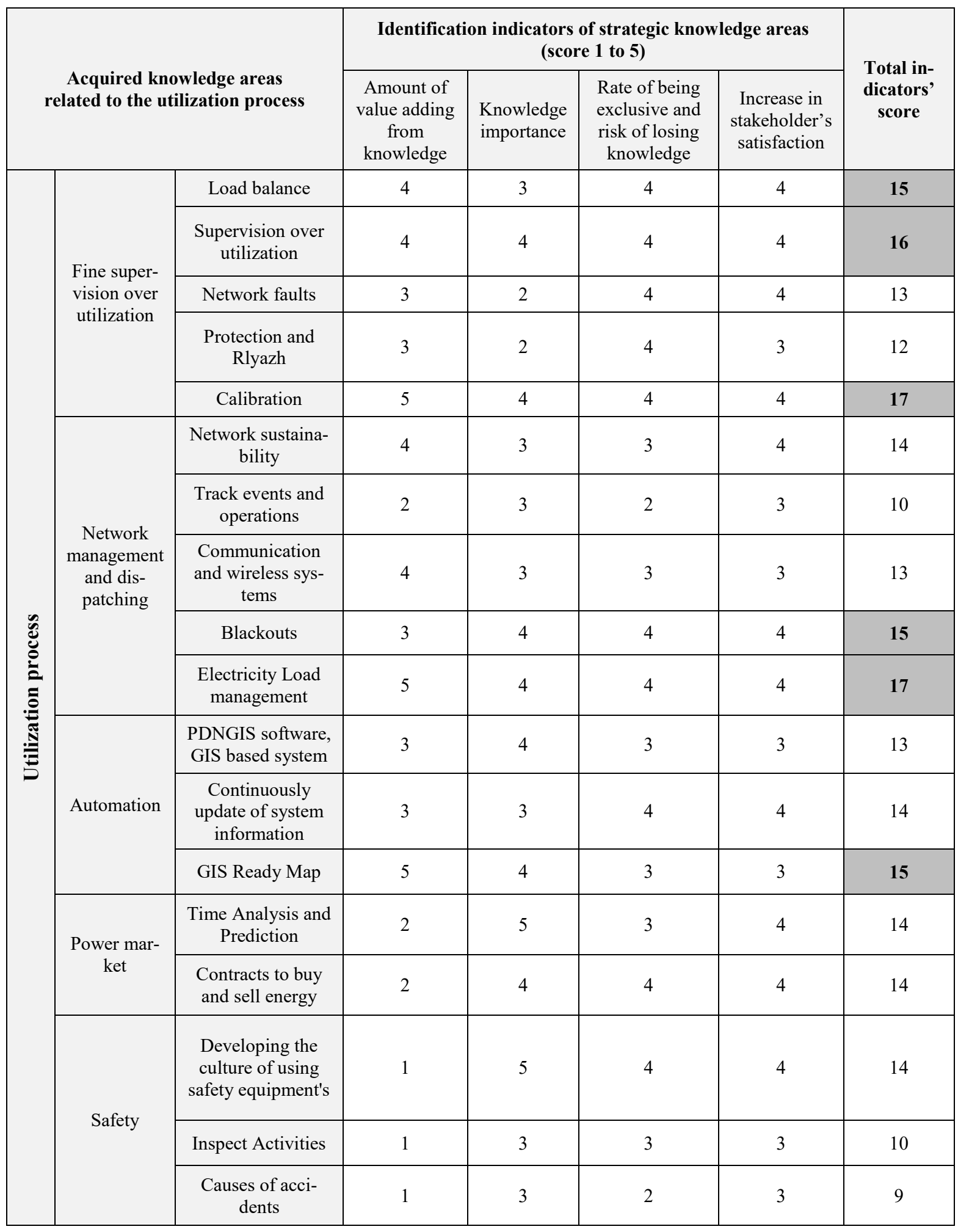




\section{Fifth step: Evaluating the knowledge level of individuals and identifying knowledge experts}

A form was prepared and sent to the process managers using knowledge classification approaches to evaluate the knowledge level of individuals and assign knowledge experts in each knowledge area. Managers were asked to score the knowledge level of their personnel in all knowledge areas on a scale of 1 to 4 . The method of scoring based on indicators is shown in Table 3 .

Table 3. Scoring guide for knowledge classification indicators

\begin{tabular}{|c|c|c|}
\hline Knowledge levels & Indicators Definition & Indicator score \\
\hline 1 & identifying, learning, understanding & 1 \\
\hline 2 & Ability to execute and use & 2 \\
\hline 3 & Ability to analyze and evaluate & 3 \\
\hline 4 & Creation, using the elements for creating a new sample & 4 \\
\hline
\end{tabular}

Table 4 is a sample of a form referred to the manager of the Utilization process. This has a list of experts and their knowledge level based on the knowledge areas. According to this table, experts are those who have gained the highest scores in the relevant knowledge area (if their scores are at least 3 ). If no one has gained score 4 in a given knowledge area, those who have obtained a score of 3 are known as experts.

In the classification of an individual's knowledge, the opinion of department managers and process managers were asked. It should be noted that other approaches like self-evaluation, peerevaluation, and a combination of these can also be used depending on the knowledge type, the classification goal and the requirements of the company.

Table 4. Evaluating the knowledge level of individuals and identifying knowledge experts of Utilization process

\begin{tabular}{|c|c|c|c|c|c|c|c|c|c|c|c|c|c|c|c|c|c|c|c|}
\hline \multirow[b]{3}{*}{ 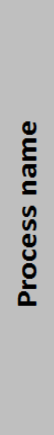 } & \multirow{3}{*}{$\begin{array}{l}\text { Process Group } \\
\text { Identified knowledge areas } \\
\text { \& Experts Identification }\end{array}$} & \multicolumn{18}{|c|}{ Utilization } \\
\hline & & \multicolumn{5}{|c|}{$\begin{array}{c}\text { Fine Supervision over } \\
\text { utilization }\end{array}$} & \multicolumn{5}{|c|}{$\begin{array}{c}\text { Network Management \& } \\
\text { Dispatching }\end{array}$} & \multicolumn{3}{|c|}{ Automation } & \multicolumn{2}{|c|}{$\begin{array}{l}\text { Power } \\
\text { Market }\end{array}$} & \multicolumn{3}{|c|}{ Safety } \\
\hline & & 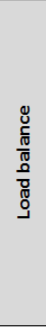 & 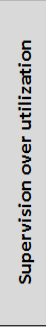 & 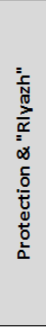 & 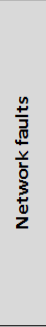 & 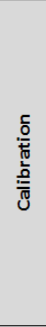 & 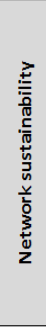 & 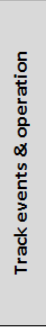 & $\begin{array}{l}\tilde{c} \\
\frac{a}{0} \\
\frac{\vec{v}}{\infty}\end{array}$ & 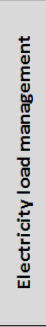 & 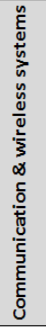 & 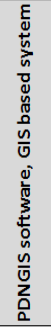 & 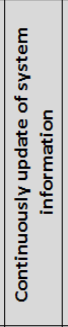 & 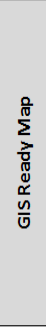 & 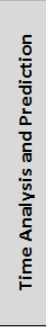 & 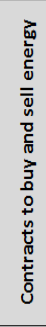 & 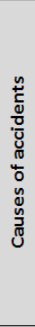 & 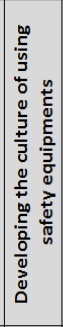 & 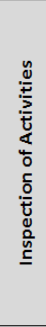 \\
\hline \multirow{17}{*}{ 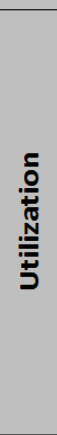 } & Employee & & & 3 & & & & & & & & & & & 3 & 3 & & & \\
\hline & Employee & & & & & & & & & & & & & & 3 & 3 & & & \\
\hline & $\begin{array}{l}\text { Employee } \\
\text { Employee }\end{array}$ & & & & & & & & & & & & & & $\frac{3}{3}$ & $\frac{3}{3}$ & & & \\
\hline & Employee & & & & & & 2 & & & & & & & 3 & & & & & \\
\hline & Expert 1 & & & & & & & & & & 4 & & & & & & & & \\
\hline & Expert 2 & & & 2 & & & & & & & & 3 & 1 & 3 & & & & 4 & 2 \\
\hline & Employee & & & & & & & & & & & 3 & 3 & 1 & & & & 1 & 1 \\
\hline & Employee & & & & & & & & & & & 3 & 2 & 2 & & & & 2 & 2 \\
\hline & Employee & & & & & & & & & & & & 2 & 2 & & & & & \\
\hline & Expert 3 & & & & & & 3 & 4 & & & 3 & & & & 3 & & & & \\
\hline & Employee & & & & & & 3 & 1 & & & 3 & & & & 2 & & & & \\
\hline & Employee & & & & & & 3 & & & & 3 & & & & & & & & \\
\hline & Expert 4 & & & & & & 3 & 4 & & & 2 & & & & & & & & \\
\hline & Employee & & & & & & 3 & 1 & & & 3 & & & & 2 & & & & \\
\hline & Employee & 2 & 3 & & & & & & & & & & & & & & & & \\
\hline & Expert 5 & 3 & 2 & 3 & 3 & 4 & & & & & & & & & 2 & & & & \\
\hline & Employee & 3 & 1 & 3 & 3 & 2 & & & & & & & & & & & & & \\
\hline \multicolumn{2}{|r|}{ Average Point of each knowledge area } & 2.7 & 2.0 & 2.8 & 3.0 & 3.0 & 2.8 & 2.5 & & & 3.0 & 3.0 & 2.0 & 2.2 & 2.6 & 3.0 & & 2.3 & 1.7 \\
\hline Level 1 & Identifying, learning \& Understanding & 0 & 0 & 0 & 0 & 0 & 0 & 2 & & & 0 & 0 & 1 & 1 & 0 & 0 & & 1 & 1 \\
\hline Level 2 & Ability to execute or use & 1 & 0 & 1 & 0 & 0 & 1 & 0 & & & 1 & 0 & 2 & 2 & 2 & 0 & & 1 & 2 \\
\hline Level 3 & Ability to analyse \& evaluate & 0 & 1 & 1 & 0 & 0 & 5 & 0 & & & 4 & 3 & 1 & 2 & 5 & 4 & & 0 & 0 \\
\hline Level 4 & Creation, using the elements to create a new sample & 0 & 0 & 0 & 0 & 0 & 0 & 2 & & & 1 & 0 & 0 & 0 & 0 & 0 & & 1 & 0 \\
\hline
\end{tabular}




\section{Sixth and seventh step: Drawing company knowledge flow maps and developing the knowledge meta-model of the company}

To draw the knowledge flows between knowledge areas, considering the chosen process approach and the current hierarchical communications between knowledge-oriented processes, the knowledge process tree as a referral model in the previous steps was chosen and presented to show the knowledge communications. It is clear that different formats can be used to edit the meta-model in companies, such as the knowledge matrix, general knowledge meta-model and specialized knowledge meta-model. Considering the results of the previous steps and the edited plan in the primary stages, knowledge models that were drawn in divided knowledge areas in the previous steps were put together and formed a meta-model that created an overview of knowledge areas of the entire processes of the company.

\section{Eighth step: Updating and developing knowledge sources and flows}

The knowledge map, by identifying the current areas, experts and the knowledge flows of the company, reveals the gaps and weak points of the company knowledge. Attending to these can lead to improved knowledge creation and learning efforts. During a number of sessions with the knowledge processes trustees, we decided that to keep the knowledge map dynamic, it should be updated every six months. In this way, the map can gradually be upgraded and developed across the entire company and meet the needs of all users. In the process of determining duties and responsibilities of the chief knowledge officer and key experts, we saw updating and constant development of the existing knowledge that exists in the knowledge map as very important.

\section{Conclusion}

Choosing the business processes as the base of creation of knowledge maps in any organization can be an effective step in improving processes and finally the organization's competitive power in today's business world. Answering the questions who (knowledge expert), what (required knowledge) and where (place of knowledge's usage) are important requirements in preparing the knowledge map. Since a process approach in business is widely discussed in recent years, this article tried to explain the manner of preparing the knowledge map in organizations using a process approach.

In this article besides reviewing the knowledge mapping priorities, we studied some of the challenges of its lack in companies. Also, the most important published methods in the field of drawing and implementing knowledge maps were studied. Given that every knowledge model presents a different viewpoint for seeing, measuring and visualizing aspects of knowledge, different knowledge modeling techniques were used in the case study. Besides considering the general principles of drawing and implementing a knowledge map along with a process map of the company, the presented model provided a good context for increasing the future success of knowledge management. In the presented model, specific features of electric power distribution companies were also studied. This article, with sharing the experiences of a company in the power distribution field, explains the actions done in that company according to the creation of a process-oriented knowledge map. Considering the results of the different steps of creating a knowledge map based on organizational processes and related analysis, we suggest solutions for improving the knowledge status of the company:

- auditing company knowledge and depicting the expected situation in each identified knowledge area;

- surveying the current and future effects of identified knowledge areas on key performance indicators;

- knowledge strategic planning and assigning the most effective strategies of knowledge situation development for each identified knowledge gap; and 
- eliciting proper, related and valuable knowledge from key experts and company competent persons in accordance with the knowledge areas situation.

\section{Acknowledgements}

This work is supported by the East Azarbaijan Electric Power Distribution Company. We thank them and all the employees who took part in the research.

\section{References}

Busch, A. P., Richards, D., \& Dampney, C. N. G. K. (2001). Visual mapping of articulable tacit knowledge. Asia-Pacific Symposium on Information Visualization, 9, 37-47.

APQC. (2012). Process classification framework. Houston, TX, APQC. Retrieved from https://www.apqc.org/pcf

Buesser, M., \& Ninck, A. (2004). Brain Space: a Virtual environment for collaboration and innovation. International Journal of Technology Management, 28, 702-713.

Chen, C. S., Lin, Y., \& Tsui, Y. K. (2007). Enhancing construction knowledge management in using knowledge breakdown structure maps. Proceedings 2007 Annual Conference of the Canadian Society of Civil Engineering, CSCE (pp. 830-840). Yellowknife, Canada.

Dabbagh, N. (2001). Concept mapping as a mindtool for critical thinking. Journal of Computing in Teacher Education, 17, 16-24.

Farquharson, F. (2004). Using knowledge mapping as strategy for building a knowledge base in a scarce skills area: A South African case study. Paper presented at the 13th National Vocational Education and Training Research Conference, Southern Cross University, Australia.

Holsapple, C. W. (2004). Handbook of knowledge management. Heidelberg. Germany: Springer.

Kim, K., Suh, E., \& Hwang, H. (2003). Building the knowledge map: An industrial case study. Journal of Knowledge Management, 7, 34-45.

Lecocq, R. (2006). Knowledge mapping: A conceptual model. Technical Report DRDC Valcartier TR 2006-118. Defence R\&D Canada - Valcartier.

Milton, N. R. (2007). Knowledge acquisition in practice. London: Springer.

Okoli, C., \& Pawlowski, S. D. (2004). The Delphi method as a research tool: An example, design considerations and applications. Information and Management, 42(1), 15-29.

Subrt, T., \& Brozova, H. (2007). Knowledge maps and mathematical modelling. Electronic Journal of Knowledge Management, 5, 497-504.

Tserng, H. P., Yin, S. Y-L., \& Lee, M. H. (2010). The use of knowledge map model in construction industry. Journal of Civil Engineering and Management, 16(3), 332-344.

Vail, E. (1999). Mapping organizational knowledge: knowledge maps as a tool for improving business process. Knowledge Management Review, 8, 10-15.

Vestal, W. (2005). Knowledge Mapping: The Essentials for Success. Houston, Texas: APQC publications.

Vestal, W., \& Lopez, K. (2003). Knowledge mapping for communities of practice. Houston, Texas: APQC publications.

Wexler, M. N. (2001). The who, what, and why of knowledge mapping. Journal of Knowledge Management, 5(3), 249-263. 


\section{Biographies}

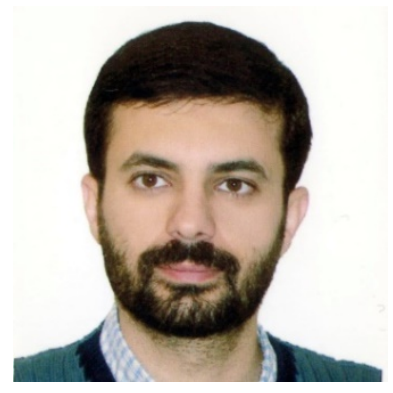

Babak Teimourpour is Assistant Professor, Department of Industrial Engineering, Tarbiat Modares University (TMU). Babak Teimourpour obtained his MS in Master of Science in Socio-Economic Systems Engineering from Institute for Research on Planning and Developement, Tehran, Iran in 1998. He teaches PhD and MS level courses. His teaching interests include Data Mining, Social Network Analysis and Knowledge Management.

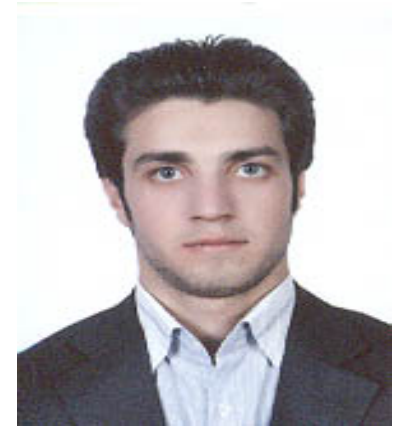

Vahid Eslami is a KM consultant and instructor. He has consulted on KM and BPM and Strategic Management in different organizations including power distribution, municipalities, automotive, oil and gas and construction. He holds a BSc in Administration Management and MSc Industrial Engineering at Tarbiat Modares University, one of Iran's top ranked universities.

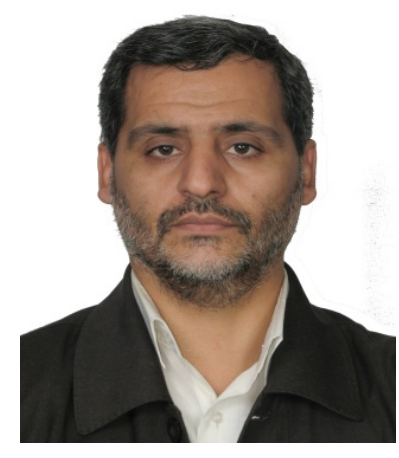

Maghsoud Mohammadi has a BSc in Human Resources Development at the Institute of Management Research and Education in Iran. He has worked for the past 20 years in human resources management and is a training and human resource planning manager in East Azarbaijan Electric Power Distribution Company. He is also company knowledge management committee secretary.

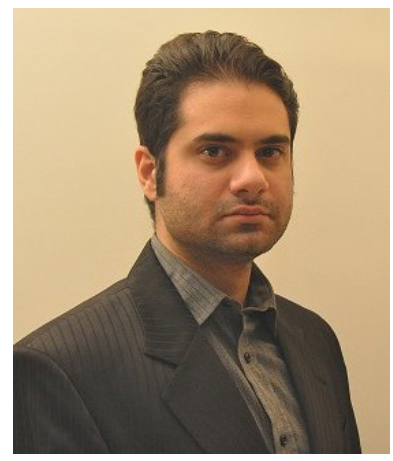

Milad Padidarfard is a project management expert. Before that he used his expertise in knowledge management in numerous organizations in Iran. Milad has a master's degree in Industrial Management with a concentration of operation research from Islamic Azad University, Firoozhoh branch in Iran. 